\title{
The effect of physically effective neutral detergent fiber on milk composition and milk yield
}

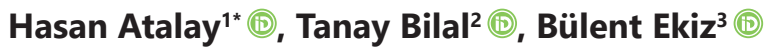 \\ ${ }^{7}$ Department of Animal Nutrition and Nutritional Diseases, Faculty of Veterinary Medicine, Balikesir University, Balikesir, Turkey. \\ ${ }^{2}$ Department of Animal Nutrition and Nutritional Diseases, Faculty of Veterinary Medicine, Istanbul University-Cerrahpasa, \\ Istanbul, Turkey. \\ ${ }^{3}$ Department of Animal Breeding and Husbandry, Faculty of Veterinary Medicine, Istanbul University-Cerrahpasa, Istanbul, Turkey.
}

Geliş Tarihi / Received: 28.10.2021, Kabul Tarihi / Accepted: 03.11.2021

\begin{abstract}
This study aims to examines the effect of the physically effective Neutral Detergent Fiber (peNDF) value of the roughage on milk composition and milk yield. Physically effective NDF varies depending on the particle length of the roughage and the amount of structural and non-structural carbohydrates in the ration. The quality, quantity, and particle length of the roughage are extremely important for rumen health. The longer the particle length of the roughage is, the more the cow ruminates and produces more saliva. The produced saliva is used to balance the rumen $\mathrm{pH}$. It is aimed to protect rumen and animal health, to improve milk production and fertility, and to make more efficient animal husbandry with the optimum preparation of the physically effective NDF levels in the ration. Providing the balance of energy, protein, and fiber required by cows in the early lactation period, maximizing the microbial yield and protecting the rumen health are possible with the optimum NDF in the ration. In this period, it is aimed to maintain the lactation peak by promoting dry matter intake. In our study, it was observed that the difference between farms was significant for the milk composition properties of peNDF content and the number of somatic cells $(P<0.001)$. It has been determined that the difference between farms on the impact of peNDF value on daily milk yield is was not significant.
\end{abstract}

Keywords: Physically effective NDF, lactation, rumen health, milk composition, milk yield

\section{Fiziksel etkin nötral deterjan lif'in süt bileşimi ve süt verimi üzerine etkisi}

Özet: Bu çalışmanın amacı kaba yemin fiziksel etkin Nötral Deterjan Lif değerinin süt bileşimi ve süt verimi üzerine etkisini incelemektir. Fiziksel etkin NDF kaba yemin partikül uzunluğuna ve rasyondaki yapısal olan ve olmayan karbonhidratların miktarına bağlı olarak değişmektedir. Rumen sağlığı açısından kaba yemin kalitesi, miktarı ve partikül uzunluğu son derece önemlidir. Kaba yemin partikül uzunluğu ne kadar artar ise inek o kadar fazla geviş getirir ve daha fazla tükrük üretir. Üretilen tükrük rumen $\mathrm{pH}$ 'sını dengelemede kullanılmaktadır. Rasyondaki fiziksel etkin NDF düzeyinin optimum şekilde hazırlanması ile rumen ve hayvan sağlığının korunması, süt ve döl veriminin iyileştirilmesi ve daha verimli bir hayvancılık yapılması amaçlanmaktadır. Erken laktasyon dönemindeki ineklerin ihtiyacı olan enerji, protein ve lif dengesinin sağlanması ile mikrobiyal verimin en üst düzeye çıkarılması ve rumen sağlığını koruması rasyondaki optimum NDF ile mümkündür. Bu dönemde kuru madde alımının teşvik edilmesi ile laktasyon pikinin sürdürülmesi hedeflenmektedir. Çalışmamızda peNDF içeriğinin süt bileşimi özellikleri ve somatik hücre sayısı için işletmeler arası farklılığın önemli olduğu görülmüştür $(p<0,001)$. peNDF değerinin süt verimi üzerinde işletmeler arası farklılığın önemsiz olduğu tespit edilmiştir.

Anahtar kelimeler: Fiziksel etkin NDF, laktasyon, rumen sağlığı, süt bileşimi, süt verimi

\section{Introduction}

Total Mixed Ration (TMR) is used in feeding dairy cattle in the world and our country. This system is the most suitable feeding system in terms of milk yield, fertility, and feeding costs. TMR is a feeding system that roughage and concentrate feed are mixed in the ration prepared according to the nutritional requirements of animals and presented as ad libitum.
In plants, carbohydrates are divided into two as structural and non-structural carbohydrates. The structural carbohydrates found in the cell wall are pectin, $\beta$-glucan, galactosides, arabinoxylan (pentosans), hemicellulose, cellulose, and lignin. Non-structural carbohydrates in the cell are organic acids, starch, and sugars. Carbohydrates are produced by photosynthesis and stored in plants. Vegetable carbohydrates consist of cell contents (sugars and 
starch) and cell wall elements (cellulose, hemicellulose, lignin). Among the carbohydrates, starch is abundant in grain feeds, and cellulose is abundant in roughages. Starch and cellulose are glucose molecules linked by different chemical bonds. Starch is digested by enzymes in the digestive system, while cellulose is digested by enzymes produced by microorganisms in the digestive system. Microorganis$\mathrm{ms}$ also digest hemicelluloses in the digestive system and convert them into organic acids (volatile fatty acids), which are the primary energy source of the organism. The main component of the plant cell wall is cellulose. Cellulose is a homogeneous glucose polymer of glucose molecules linked by $\beta-1,4$ glycoside bonds. It is only found in cotton in its purest form. Hemicellulose is a heterogeneous polysaccharide with 5 and 6 carbons and linked by $\beta-1,4$ glycoside bonds such as xylose, arabinose, mannose, galactose, and glucose. Hemicellulose is soluble in diluted alkalis $(\mathrm{NaOH})$, but cellulose is insoluble. Lignin has a structure like a glue that binds cellulose and hemicellulose together. Lignin is not a carbohydrate and has a water-repellent nature. The basic structure of lignin is phenyl propane derivative. Microorganisms in the rumen break down cellulose in feeds with the enzymes they synthesize and converted into volatile fatty acids, carbon dioxide, and methane gas. Thus energy is obtained (Kirchgessner 1985).

Forage crops contained in roughages are crucial in feeding dairy cattle. Forage crops are indispensable for ruminant nutrition. Since forage crop cultivation is insufficient in Turkey, cattle breeding confronts a roughage shortage. The ration should include the amount of a nutrient that will promote the desired yield level according to the animals' genetic capacity. The forage crop should be harvested when it contains the most protein. This period is also the period when the amount of Neutral Detergent Fiber (NDF) is the least. Ration NDF rate should not exceed 30\%, and the Acid Detergent Fiber (ADF) rate should not exceed $19 \%$ for cattle producing high milk yield. Animals like to consume high-quality roughage. When compared to high-quality alfalfa consumption, low-quality alfalfa consumption causes economic damage according to dry matter intake and milk yield rates. Planting fodder crops together (carbohydrates-rich Poaceae and protein-rich Legume) improves the quality of feed. The amount and ratio of fiber (NDF, ADF) found in forage crops determine the quality. The higher the fiber ratio in the fodder crop is, the lower the digestion rate is. While the structural, fibrous carbohydrates, namely hemicellulose, cellulose, lignin in the cell wall form the NDF fraction, cellulose and lignin form the ADF fraction (Budak and Budak 2014).

The Weende chemical analysis method is used to determine the nutrients in the feed. While this method shows the chemical composition of feed nutrients as raw nutrient content, it shows cellulose, hemicellulose, lignin contents as crude cellulose. In the Van Soest analysis method, the chemical composition of feeds is divided into two as cell wall and cell contents. Van Soest's analysis method specifies the fibrous structures (cellulose, hemicellulose, and lignin comprising the cell wall) in the NDF, ADF, Acid Detergent Lignin (ADL), fractions. The Van Soest method is based on the principle of determining the remaining cell wall amount as NDF, ADF, ADL after the feed sample is boiled with acid and neutral detergent, filtered, dried, and weighed (Van Soest et al. 1991).

In recent years, NDF and ADF values have been used instead of raw cellulose (cellulose, hemicellulose, lignin) values. NDF and ADF values provide information about the amounts of some compounds in the plant cell wall. Since these woody substances in the plant's structure are difficult to digest and turn into energy, NDF and ADF values are extremely important for healthy, efficient, and correct animal nutrition. NDF can be characterized as the principal part of the plant cell wall. It contains compounds such as hemicellulose, cellulose, lignin. The NDF value of the feed is a ratio that determines the amount of dry matter that the animal can directly consume according to its body weight. ADF value is obtained by subtracting the amount of hemicellulose from the NDF value. The ADF value of the feed gives the digestible dry matter amount. The digestible dry matter consumption of the cow ensures the digestible energy to be calculated. The more digestible dry matter the animal consumes, the more energy it produces, and the more energy, milk, and meat it generates. The low ADF amount of the feed indicates that it has a high digestion degree and energy. The low amount of NDF and ADF in the feed shows that its consumption, digestion, and energy are high, while the high amount of NDF and ADF shows that its consumption, digestion, and energy are low. The digestibility degree of intracellular compounds (starches, fats, proteins, sugars, pectins) is much higher than cell wall compounds. Therefore, the forage cell wall components (NDF, ADF) should be at a low value. The excess amount of NDF and ADF 
in the feed reduces dry matter consumption, digestibility, and energy intake. In the digestive system, indigestible feed materials prevent dry matter consumption as they create a feeling of satiety. Thus, the critical nutrients cannot be taken for high productivity. Easily digestible nutrients in the digestive system increase animal's dry matter consumption and energy. Minumum \% NDF and \% ADF requirements in the rations was reported as: NDF $=25-30$ (Herdt 2014), 25-33 (NRC 2001), and ADF $=17-21$ (NRC 2001). The animal consumption limit of the NDF was estimated as $1.2 \%$ of the animal's weight (Beauchemin 1996).

The TMR consumed by the cow contains 65 $75 \%$ dry matter. Starch, pectin, and sugar must be high in TMR for maximum microbial protein formation. If the forage plant is harvested before or at the beginning of flowering, it contributes to the increase in milk yield. Roughages can be listed according to their quality as alfalfa hay, alfalfa silage, corn silage, hay silage, and wheat silage. In terms of the roughage ratio in TMR, if roughage NDF digestion increases, dry matter consumption and milk yield increase. If the amount of NDF in TMR is above $25 \%$, the rumen $\mathrm{pH}$ value will be greater than 6 . Grain feeds are listed as wheat, barley, oat, corn, and sorghum according to their decomposition rate in the rumen. Finely ground maize is better digested than crushed corn (Oba and Allen 1999).

This study aims to examine the effect of the physically effective NDF (peNDF) value of roughage on milk composition and milk yield.

\section{Material and Method}

Feed analysis: peNDF value, particle size. The study was carried out in two different commercial dairy farms in Balıkesir (coordinates: $39^{\circ} 42^{\prime} 31^{\prime \prime} \mathrm{N} 27^{\circ} 53^{\prime} 11^{\prime \prime} \mathrm{E}$, $\left.39^{\circ} 48^{\prime} 51^{\prime \prime} \mathrm{N} 27^{\circ} 57^{\prime} 26^{\prime \prime} \mathrm{E}\right) .0 .5 \mathrm{~kg}$ of fresh TMR feed samples were taken separately from both dairy far$\mathrm{ms}$, brought to the laboratory in airtight bags, and kept at $-20^{\circ} \mathrm{C}$ until analysis. After the feed samples were cut into small pieces $(1 \mathrm{~cm})$, they were dried in the oven at $65^{\circ} \mathrm{C}$ for 48 hours until the weight did not change and the nutrient levels were determined. TMR forage samples were ground in a $1 \mathrm{~mm}$ sieve mill (Retsch ZM 200 ultra centrifugal mill) for analysis. Nutrient values of TMR feed were analyzed according to AOAC (1990) for dry matter (method
934.01), Crude Ash (method 942.05), Crude Protein (method 954.01), Ether Extract (method 920.39), Crude Cellulose (method 962.09), and Starch (method 920.40). NDF, ADF, and ADL analysis of TMR feed samples were analyzed using the automatic fiber device Gerhard FT12 (2014) according to the methods reported by Van Soest et al. (1991). Penn State Particle Separator (PSPS) TMR was helpful to estimate particle size. The separator has three sieves and a sub-sieve (cup). The diameters of the sieves were $19 \mathrm{~mm}, 8 \mathrm{~mm}, 1.18 \mathrm{~mm}$, respectively, from the top. Each TMR sample particle size was found by horizontally shaking at least 66-times per minute in PSPS. The physical efficacy factor (pef) was calculated as the percentage of particles retained on the $1.18 \mathrm{~mm}$ screen of PSPS. The peNDF value was determined by multiplying pef by the proportion of NDF in the TMR (Mertens 1997; Kononoff et al. 2003a; Yang and Beauchemin 2005).

Milk analysis: For preservative purposes, milk samples were collected into sterile sample containers containing potassium dichromate and brought to the laboratory under the cold chain. Protein and fat in the milk samples were determined using an autoanalyzer (Bentley Instruments Inc USA) according to the manufacturer's instructions and Iñón et al., (2004). Somatic cell numbers and total bacterial numbers were determined with the IRT method (IR FlexCam S, Infrared Solutions Inc USA), under ISO21187/IDF 196, according to Berry et al. (2003) method.

Statistical analysis: The statistical analysis of milk composition properties was compared by General Linear Model analysis. In the current statistical model, farm, measurement month, and farm $\times$ measurement month interaction factors took place as fixed effects. An independent sample t-test was used to compare the dairy farms in terms of daily milk yield. Statistical analyzes were made using the SPSS 13.0 program.

\section{Results}

Table 1 shows the Nutrients Composition (DM\%) of the TMR, Table 2 shows the particle size distributions, NDF, and peNDF values of the TMR (DM\%), Table 3 shows the effect of peNDF value on milk composition and Table 4 shows the impact of peNDF value on milk yield. 
Table 1. Nutrient composition (DM\%) of total mixed ration (TMR).

\begin{tabular}{lcc}
\hline Item & $\mathbf{1}^{\text {st }}$ Dairy Farm TMR & $\mathbf{2}^{\text {st }}$ Dairy Farm TMR \\
\hline DM \% & 49.28 & 52.48 \\
EE & 4.96 & 4.40 \\
CP & 16.82 & 16.75 \\
CF & 18.43 & 11.15 \\
CA & 7.22 & 7.83 \\
Starch & 22.17 & 32.39 \\
NDF & 37.07 & 30.08 \\
ADF & 26.14 & 18.75 \\
ADL & 3.16 & 2.86 \\
\hline
\end{tabular}

$\mathrm{DM}=$ Dry Matter, $\mathrm{EE}=$ Ether Extract, $\mathrm{CP}=$ Crude Protein, $\mathrm{CF}=\mathrm{Crude}$ Fiber, $C A=$ Crude Ash, NDF= Neutral Detergent Fiber, ADF= Acid Detergent Fiber, $A D L=$ Acid Detergent Lignin
Table 2. Particle sizes distribution, NDF, and peNDF values of the total mixed ration (DM\%).

\begin{tabular}{lcc}
\hline $\begin{array}{l}\text { Particle size } \\
\text { distribution (DM\%) }\end{array}$ & $\begin{array}{c}\mathbf{1}^{\text {st }} \text { Dairy Farm } \\
\text { TMR }\end{array}$ & $\begin{array}{c}\text { 2 }^{\text {st }} \text { Dairy Farm } \\
\text { TMR }\end{array}$ \\
\hline$>19 \mathrm{~mm}$ & 14.62 & 6.74 \\
$19-8 \mathrm{~mm}$ & 42.08 & 36.50 \\
$8-1.18 \mathrm{~mm}$ & 31.86 & 33.33 \\
$<1.18 \mathrm{~mm}$ (Pan) & 18.42 & 23.41 \\
pef $^{1}$ & 0.81 & 0.76 \\
NDF $^{2}$ & 37.07 & 30.08 \\
\hline peNDF & 30.02 & 22.86 \\
\hline
\end{tabular}

Table 3. The effect of physically effective NDF (peNDF) value on milk composition.

\begin{tabular}{lccccc}
\hline \multirow{2}{*}{ Item } & \multicolumn{2}{c}{$\mathbf{1}^{\text {st }}$ Dairy Farm } & \multicolumn{2}{c}{$\mathbf{2}^{\text {st }}$ Dairy Farm } & \multirow{2}{*}{ P-value } \\
\cline { 2 - 5 } Milk fat \% & Mean & SE & Mean & SE & $<0.001$ \\
Milk protein \% & 3.89 & 0.021 & 4.47 & 0.015 & $<0.001$ \\
Milk lactose \% & 3.01 & 0.009 & 3.09 & 0.006 & $<0.001$ \\
Dry matter \% & 4.89 & 0.004 & 4.85 & 0.003 & $<0.001$ \\
Urea \% & 12.16 & 0.029 & 12.51 & 0.020 & $<0.001$ \\
\hline Somatic cell count (cells/ml) & 12.58 & 0.059 & 11.94 & 0.042 & $<0.001$ \\
\hline
\end{tabular}

Between-farm differences are significant in milk composition characteristics and somatic cell count $(P<0.001)$.

Table 4. The effect of physically effective NDF (peNDF) value on milk yield.

\begin{tabular}{lcccccc}
\hline & \multicolumn{2}{c}{$\mathbf{1}^{\text {st }}$ Dairy Farm } & \multicolumn{2}{c}{$\mathbf{2}^{\text {st }}$ Dairy Farm } & P-value \\
\cline { 2 - 5 } Milk yield, $\mathrm{kg} / \mathrm{d}$ & Mean & SE & Mean & SE & \\
\hline
\end{tabular}

\section{Discussion and Conclusion}

It has been reported that the high peNDF content of the ration has no effect on feed intake, milk production, and milk composition, and also, the high digestibility resulting from the high peNDF in the ration does not significantly improve milk yield and milk composition in mid-lactating cows (Yang and Beauchemin 2005). It has been stated that when there is a sufficient amount of peNDF in the ration, the milk fat percentage may be constant (Gencoglu et al. 2007).

It has been stated that the decrease in particle size of corn silage and an increase in volatile fatty acid do not affect rumen pH (Kononoff et al. 2003b). Although chewing activity is closely related to roughage particle size, it has been reported that its effect on rumen $\mathrm{pH}$ is small, and also, when the NDF level meets the recommended level, the specified factors other than particle size have critical importance on rumen $\mathrm{pH}$ level. Although small particle size clover silage-based feeding results in animals consuming more feed, it has been stated that milk yield is not affected by this situation (Kononoff and Heinrichs 2003c).

It has been suggested that peNDF measured by Penn State Particle Separator (PSPS) has a weak predictive effect on rumen $\mathrm{pH}$ level, but measuring particle size using PSPS can help understand the factors affecting feeding behavior (Kononoff and Heinrichs 2003d).

In a study in which cottonseed and DDG roughages were used instead of alfalfa silage, according 
to the milk fat test, the ration peNDF values were found $58 \%$ and $31.5 \%$, respectively. It was stated that these peNDF rates did not affect milk yield but caused an increase in milk fat and protein yield (Clark and Armentano 1993). The current study is also consistent with these results, and it has been observed that the $30.91 \%$ and $22.86 \%$ of peNDF ratio of rations did not affect the milk yield and the milk composition properties.

In a study using alfalfa hay and wheat straw instead of corn silage, peNDF values were found between 33.24 and 36.30, and it was stated no effect on milk composition and yield (Gencoglu et al. 2007). Contrary to these results, in our study, peNDF values in the farms were different, between 22.86 and 30.02, and the difference between the farms were found significant in the milk composition characteristics and the number of somatic cells $(P<0.001)$.

Determining the NDF effectiveness for maintaining milk fat production and optimizing ruminal fermentation depends on the structural properties and particle length of NDF, which affects milk fat production, ruminal $\mathrm{pH}$, and chewing activity (Mertens 1997).

In conclusion, there is no information available about the cattle's peNDF requirements in TMR. Besides, it is not known that whether the peNDF value has any effect on milk composition and milk yield. Therefore, more studies on peNDF are needed.

Author contributions: HA designed and carried out the experiments, BE statistical analysed the data, HA wrote the paper, TB critical reviewed.

Conflicts of interest: The authors declare that there are no conflicts of interest.

Ethical Statement: This study does not present any ethical concerns.

\section{References}

AOAC (1990) Association of Official Analytical Chemists, 15th ed. Washington, D.C. USA

Beauchemin K A. (1996) Using ADF and NDF in dairy cattle diet formulation-a western Canadian perspective. Animal Feed Science and Technology. 58, 101-111.

Budak F, Budak F. (2014) Quality on forage plants and factors effecting forage quality. Turkish J Sci Review. 7, 1-6.

Berry RJ, Kennedy AD, Scott SL, Kyle BL, Schaefer AL. (2003) Daily variation in the udder surface temperature of dairy cows measured by infrared thermography: Potential for mastitis detection. Can J Anim Sci. 83, 687-693. https://doi: 10.4141/ A03-012.

Clark PW, Armentano LE. (1993) Effectiveness of neutral detergent fiber in whole cottonseed and dried distillers grains compared with alfalfa haylage. J Dairy Sci. 76, 26442650. https://doi: 10.3168/jds.S0022-0302 (93)77600-6.

Iñón FA, Garrigues S, de la Guardia M. (2004) Nutritional parameters of commercially available milk samples by FTIR and chemometric techniques. Anal Chim Acta. 513, 401-412. https://doi:10.1016/j.aca.2004.03.014.

Gencoglu H, Turkmen II, Deniz G, Biricik H. (2007) The effect of partial replacement of corn silage on rumen degradability, milk production and composition in lactating primiparous dairy cows. Ital J Anim Sci. 6, 71-80. https://doi: 10.4081/ ijas.2007.71.

Herdt T. (2014) Nutritional requirements of dairy cattle. MSD Merck Veterinary Handbook, Nov 2014. Kenilworth, NJ, USA: Merck, 1-9.

Kirchgessner M. (1985) Hayvan Besleme. Öğretim, Öğrenim ve Uygulama Önerileri. Çeviren Asım Kılıç, Tübitak Yayınları, Yayın No: 611 VHAG Seri No:21, Ankara.

Kononoff PJ, Heinrichs AJ, Buckmaster DR. (2003a) Modification of the Penn State forage and total mixed ration particle separator and the effects of moisture content on its measurements. J Dairy Sci. 86, 1858-1863. https://doi: 10.3168/jds.S0022-0302(03)73773-4.

Kononoff PJ, Heinrichs AJ, Lehman AH. (2003b) The effect of corn silage particle size on eating behavior, chewing activities, and rumen fermentation in lactating dairy cows. J Dairy Sci. 86, 3343-3353. https://doi: 10.3168/jds.S0022-0302 (03)73937-X.

Kononoff PJ, Heinrichs AJ. (2003c) The effect of reducing alfalfa haylage particle size on cows in early lactation. J Dairy Sci. 2003 Apr;86(4), 1445-1457. https://doi: 10.3168/jds.S0022$0302(03) 73728-X$

Kononoff PJ, Heinrichs AJ. (2003d) The effect of corn silage particle size and cottonseed hulls on cows in early lactation. $J$ Dairy Sci. 86, 2438-2451. https://doi: 10.3168/jds.S0022-0302 (03)73838-7.

Mertens DR. (1997) Creating a system for meeting the fiber requirements of dairy cows. J Dairy Sci. 80, 1463-1481. https:/ doi: 10.3168/jds.S0022-0302 (97)76075-2.

National Research Council (NRC). (2001) Nutrient requirements of dairy cattle Seventh edition, Washington DC National Academies Press.

Oba M, Allen MS. (1999) Evaluation of the importance of the digestibility of neutral detergent fiber from forage: effects on dry matter intake and milk yield of dairy cows, J Dairy Sci. 82 589-596. https://doi: 10.3168/jds.S0022-0302(99)75271-9.

Van Soest P, Robertson JB, Lewis BA. (1991) Methods for dietery fiber, neutral detergent fiber and nonstarch polysaccharides in relation to animal nutrition. J Dairy Sci. 74, 3583-3597. https://doi: 10.3168/jds.S0022-0302 (91)78551-2.

Yang WZ, Beauchemin KA. (2005) Effect of physically effective fiber on digestion and milk production by dairy cows fed diets based on corn silage. J Dairy Sci. 88, 1090-1098. https:// doi: 10.3168/jds.S0022-0302 (05)72776-4. 